ISSN 0103-8478

\title{
Growth and yield of anthurium in response to gibberellic acid
}

\author{
Crescimento e produção de antúrio em resposta a ácido giberélico
}

\author{
Juliana Domingues Lima ${ }^{\mathrm{I}^{*}}$ Nathalia Felipe Ansante ${ }^{\mathrm{I}}$ Edson Shigueaki Nomura ${ }^{\mathrm{II}}$ \\ Eduardo Jun Fuzitani ${ }^{I I}$ Silvia Helena Modenese-Gorla da Silva ${ }^{I}$
}

\section{ABSTRACT}

Gibberellic acid $\left(G A_{3}\right)$ induces flowering of plants of various genera of the Araceae family. Therefore, it was evaluated the effect of $\mathrm{GA}_{3}$ on the growth and yield of Anthurium andraeanum cv. 'Apalai'. For this purpose, micropropagated seedlings were planted in nursery beds under $70 \%$ shade. The experimental design was completely randomized in subdivided plots with eight replications. The growth regulation effect was assessed in each plot and the time to flowering after the start of the treatments was assessed in each subplot. The GA concentrations were $0,150,300,450$ and $600 \mathrm{mg} \mathrm{L}^{-1}$, applied every 60 days by spraying on the leaves. The applications and evaluations started after the production of marketable floral stems. Every month the number of leaves was counted and their dimensions were measured, while every week the presence of inflorescences and the point of their commercial harvest were assessed and the respective dimensions were measured. Application of $\mathrm{GA}_{3}$ at 150, 300 and $450 \mathrm{mg} \mathrm{L}^{-1}$ promoted an increase in the leaf area. However, there was no increase in the number of inflorescences produced or their quality, making it impossible to recommend the use of this growth regulator for commercial production of this flower.

Key words: Anthurium andraeanum Linden ex André, gibberellin, growth regulator, flowering.

\section{RESUMO}

Ácido giberélico $\left(A G_{3}\right)$ induz o florescimento de plantas de diversos gêneros da família Araceae. Assim sendo, foi avaliado o efeito do $\mathrm{AG}_{3}$ no crescimento e produção de Anthurium andraeanum $\mathrm{cv}$. 'Apalai'. Para tal, mudas micropropagadas foram plantadas em canteiros sob viveiro com $70 \%$ de sombreamento. $O$ delineamento experimental foi inteiramente casualizado em parcelas subdivididas com oito repetições. O efeito do regulador de crescimento foi avaliado na parcela, e o tempo após o início dos tratamentos, avaliado na subparcela. As concentrações de $A G_{3}$ foram 0, 150, 300, 450 e $600 \mathrm{mg} \mathrm{L}^{-1}$, aplicadas a cada 60 dias, por meio de pulverização foliar. As aplicações e avaliações foram iniciadas após a produção de hastes florais comercializáveis. Mensalmente, foi avaliado o número de folhas e determinadas suas dimensões. Semanalmente, foi avaliada a presença da inflorescência e, no ponto de colheita comercial, suas dimensões. $A G_{3}$ a 150,300 and $450 \mathrm{mg} \mathrm{L}^{-1}$ promoveu aumento na área foliar da planta. No entanto, não houve aumento do número de inflorescências produzidas ou qualidade, o que torna inviável a recomendação deste regulador de crescimento para uso em área de produção comercial.

Palavras-chave: Anthurium andraeanum Linden ex André, giberelina, regulador de crescimento, florescimento.

\section{INTRODUCTION}

Anthurium is the largest and most morphologically diverse genus of the Araceae family, composed of over 1,000 species (MARTIN et al., 2003), of which around 450 occur in Brazil (TOMBOLATO et al., 2004). The majority of these species are perennial herbaceous plants. They are often cultivated for ornamental purposes due to their attractive inflorescences, such as Anthurium andraeanum Linden ex André, which has high commercial value as a garden plant, potted plant or for its cut flowers (STANCATO \& SILVEIRA, 2006).

As a cut flower, anthurium is one of the main tropical species, only behind orchids, due to its beauty and long postharvest life (DUFOUR \&

'Câmpus Experimental de Registro, Universidade Estadual Paulista “Júlio de Mesquita Filho” (UNESP), Rua Nélson Brihi Badur, 430, Vila Tupy, 11900-000, Registro, SP, Brasil. E-mail: judlima@registro.unesp.br. *Autor para correspondência.

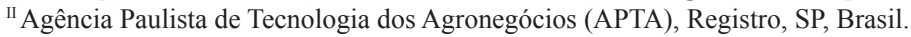


GUÉRIN, 2003). In the reproductive phase, which lasts throughout the ear, it produces inflorescences that emerge from the base of each leaf(HIGAKI et al., 1984), maintaining the leaf-inflorescence sequence throughout the total life cycle of the plant, with yield and quality depending on the environmental, nutritional and management conditions. One of the main factors that can affect the production of cut anthurium flowers is the slow growth of the inflorescences, the speed of which is controlled by the source-sink ratio (DUFOUR \& GUÉRIN, 2003; 2005). There can even be competition for photo assimilates between the leaves and inflorescences (DAÏ \& PAULL, 1990).

The growth and development of plants can be manipulated by the use of plant regulators, for this reason the use of these substances in floriculture has increased. In this respect, gibberellic acid $\left(\mathrm{GA}_{3}\right)$ has been shown to induce flowering in species of the Araceae family (HENNY \& HAMILTON, 1992; BOSCHI et al., 1998; ZHENG \& CHAO, 2004; CHANDARAPA et al., 2006; HATIBARUA et al., 2006). Therefore, the aim of this study was to assess the effect of $\mathrm{GA}_{3}$ on the growth and flower yield of anthurium cv. Apalai.

\section{MATERIAL AND METHODS}

The experiment was conducted in an area of a flower farm located in the municipality of PariqueraAçu, São Paulo state, Brazil, located at $24^{\circ} 36^{\prime} 31^{\prime \prime} \mathrm{S}$ and $47^{\circ} 53^{\prime} 48^{\prime \prime} \mathrm{O}$ and at an altitude of $25 \mathrm{~m}$. According to the Köppen classification, the region's climate is humid tropical, with a well-defined dry season (Af).
The accumulated rainfall in the experimental period was $1,573 \mathrm{~mm}$ year $^{-1}$ and the average minimum and maximum temperatures were $25.9^{\circ} \mathrm{C}$ and $16.7^{\circ} \mathrm{C}$, respectively (Figure 1). The predominant soil in the experimental area was Oxisols, Typic Hapludox (SOIL SURVEY STAFF, 2010). Chemical analysis of the surface layer $(0-0.2 \mathrm{~m})$ was carried out before the experiment, with the following results: $\mathrm{pH}$ $\left(\mathrm{CaCl}_{2}\right)$ : 5.8 ; P (resin): $2 \mathrm{mg} \mathrm{dm}^{-3}$; organic matter: $50 \mathrm{~g}$ $\mathrm{dm}^{-3} ; \mathrm{K}: 2.3 \mathrm{mmol}_{\mathrm{c}} \mathrm{dm}^{-3}$; Ca: $116 \mathrm{mmol}_{\mathrm{c}} \mathrm{dm}^{-3}$; $\mathrm{Mg}$ : $30 \mathrm{mmol}_{\mathrm{c}} \mathrm{dm}^{-3}$; potential acidity: $20 \mathrm{mmol}_{\mathrm{c}} \mathrm{dm}^{-3}$; and base saturation (V): $88 \%$. The plant material used was anthurium cv. Apalai in the adult phase, whose seedlings had been obtained by micropropagation, acclimated and planted in September 2009, spaced at $0.40 \mathrm{x} 0.40 \mathrm{~m}$ intervals in beds measuring $1.20 \mathrm{~m}$ in width, laid out in a nursery area covered at a height of three meters with black netting to provide $70 \%$ shade.

The experimental design was totally randomized, in subdivided plots, with eight replications. The effect of applying the growth regulator was assessed in each plot and the effect of time from the start of the treatments (weeks or months) was assessed in the subplots. The treatments consisted of solutions with different concentrations of $\mathrm{GA}_{3}$ (zero, 150, 300, 450 and $600 \mathrm{mg} \mathrm{L}^{-1}$ ), applied every 60 days for one year, by manual spraying on the leaves, using a commercial product $\left(100 \mathrm{~g} \mathrm{~kg}^{-1} \mathrm{GA}_{3}\right)$ dissolved in water, with addition of a spreader-sticker. The fertilization was maintained with the application of $20 \mathrm{~g}$ per plant and a formulation of NPK 10-10-10 every two months. During the experiment, the lateral buds were eliminated, maintaining only one plant per clump. The plants did not receive any irrigation or leaf

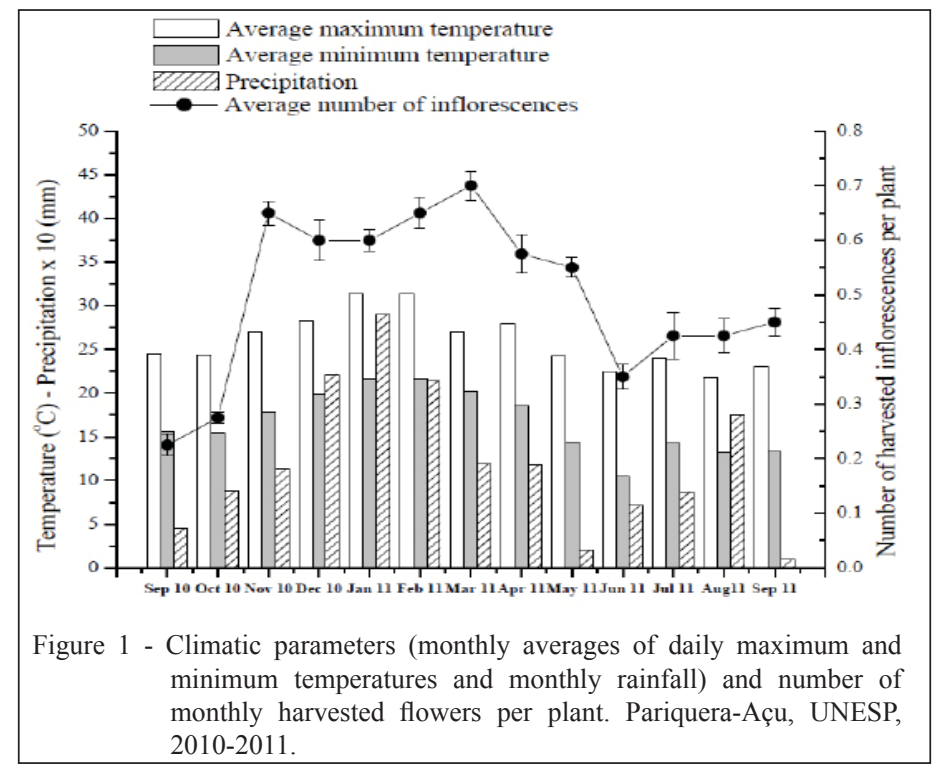

Ciência Rural, v.44, n.8, ago, 2014. 
trimming. Every four months, $0.04 \mathrm{~m}^{3} \mathrm{~m}^{-2}$ of sawdust was distributed on the surface of the plots to maintain the soil moisture and reduce the occurrence of weeds.

The evaluation of the plants started in September 2010, the point when it was possible to market the inflorescences harvested. Every month the number of leaves was counted and their dimensions were measured (maximum width and length and petiole length). The total leaf area was determined by the sum of the areas of the individual leaves, estimated by equation $L A=0.9672 * L * W$, where $L A$ is the leaf area $\left(\mathrm{cm}^{2}\right)$ and $\mathrm{L}$ and $\mathrm{W}$ are the maximum length and width (MODENESE-GORLA DA SILVA et al., 2008). Every week the presence of inflorescence and commercial harvest point (half to three-quarters of the true flowers open on the spadix) were evaluated and the inflorescence was harvested to determine its dimensions (size of the floral stem, width and length of the spathe and length of the spadix), along with assessment of the flower quality (appearance).

The statistical analysis was carried out with the Sisvar v.4.2 program. Initially, the data gathered were submitted to tests of normality (Lilliefors test) and homogeneity (Cochran test), which showed it was not necessary to transform the data. Then analysis of variance was performed with application of the F-test $(\mathrm{P}<0.05)$ and the differences of the means were compared by the Tukey test $(\mathrm{P}<0.05)$. Polynomial regression was used to determine the most adequate $\mathrm{GA}_{3}$ concentration and the effect of growth time on the plants, with the models chosen based on the significance of the F-test $(\mathrm{P}<0.05)$.

\section{RESULTS AND DISCUSSION}

Although the minimum base temperature of $14^{\circ} \mathrm{C}$ and maximum base temperature of $35^{\circ} \mathrm{C}$ (DUFOUR \& GUÉRIN, 2003) were exceeded on some days (Figure 1), overall the climate conditions were suitable for anthurium cultivation, because the plants showed linear leaf tissue growth (Figure 2A), independent of the treatment with $\mathrm{GA}_{3}$.

Gibberellin affected the vegetative growth of anthurium, with the response being

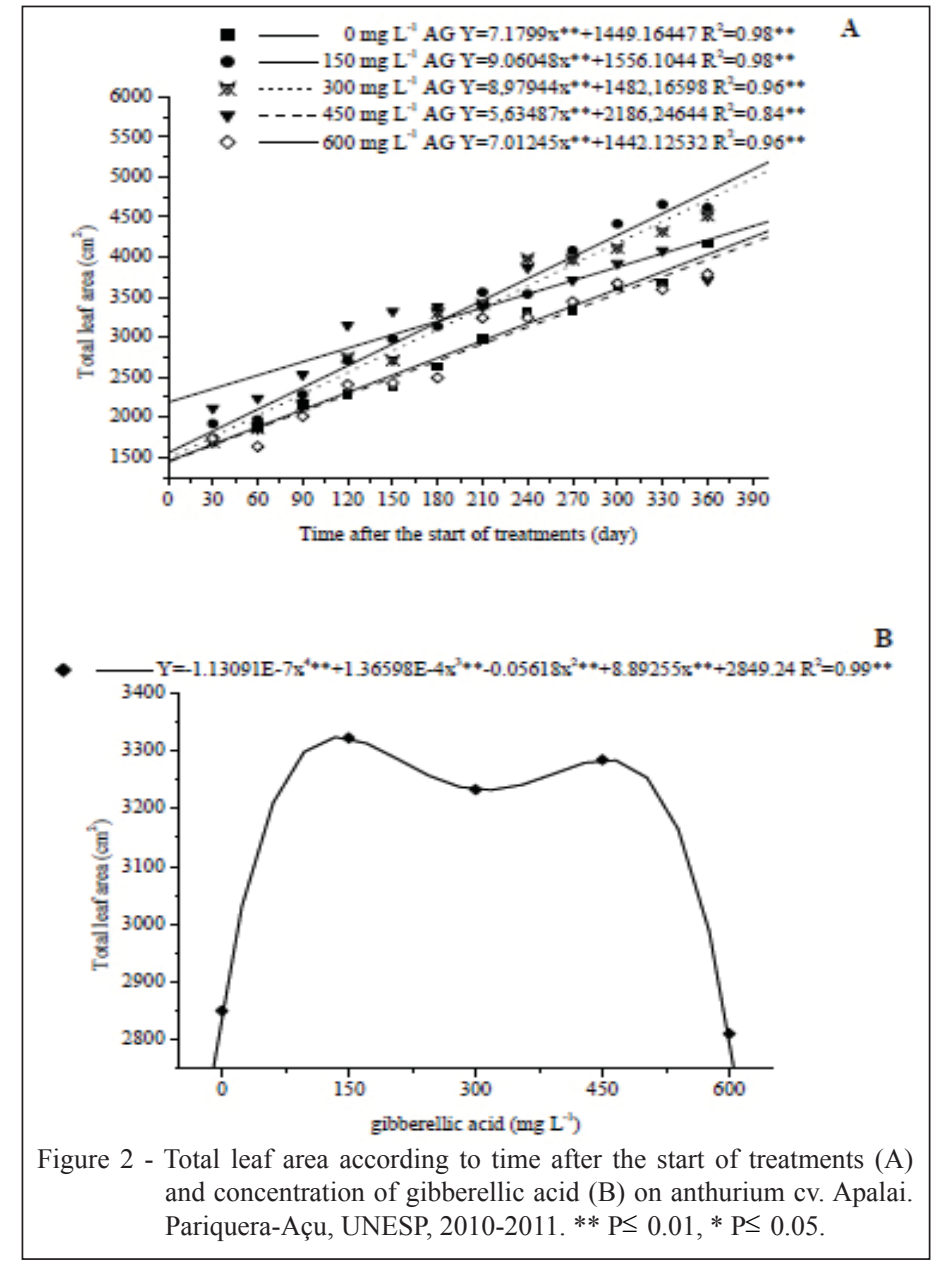

Ciência Rural, v.44, n.8, ago, 2014. 
dependent on the concentration (Figure 2B). Lower concentrations of growth regulator $\left(150-450 \mathrm{mg} \mathrm{L}^{-1}\right.$ $\mathrm{GA}_{3}$ ) increased the level endogenous gibberellin, which promoted the increase in leaf area, while high concentration $\left(600 \mathrm{mg} \mathrm{L}^{-1} \mathrm{GA}_{3}\right)$ promoted excessive rise in the level endogenous gibberellin nullifying the response (Figure 2B). Gibberellin stimulates the expression of enzymes involved in cell wall loosening and genes controlling cell division and also stimulates microtubule rearrangements associated with cell expansion (AMBER et al., 2012). The cell expansion occurs partly through effects on downstream signaling and auxin transport (AMBER et al., 2012). On the other hand, excessive gibberellin induces acidification in cell (MIYAMOTO et al., 2012), which influences the auxin transport. HENNY \& HAMILTON (1992) suggested 500 $\mathrm{mg} \mathrm{L}^{-1} \mathrm{GA}_{3}$ as the maximum concentration of anthurium, in agreement with the results obtained in this study.

The increase in the leaf area can imply greater interception of sunlight and consequently greater photosynthetic capacity of the plant (source) and higher availability of photoassimilates for growth of inflorescences or new leaves (sinks). Nevertheless, there were no differences in the yield and growth of the inflorescences between plants treated with $\mathrm{GA}_{3}$ at concentrations of 150,300 and $450 \mathrm{mg} \mathrm{L}^{-1}$ and those treated with water or $600 \mathrm{mg}$ $\mathrm{L}^{-1}$ of $\mathrm{GA}_{3}$ for any of the variables analyzed. This can be explained by the higher exportation of photoassimilates to the young leaves or other organs, such as roots. On the other hand, there may have been a reduction in the source strength as a result of the greater shade provided by the increase in the size and number of leaves.

In a study of the effect of leaf trimming, with plants of the same age, cultivar and growing conditions, the plants maintained with four and five leaves did not differ from those left with all their leaves in relation to yield of inflorescences and their dimensions, even though the trimming represented decreases of 54 and $75 \%$, respectively, in leaf area (NOMURA et al., 2011). This demonstrates that leaf area (source) was not a limiting factor for determination of the number of inflorescences, their growth and quality. The fact that $\mathrm{GA}_{3}$ only promoted growth of the leaf blade consequently did not bring any benefit in terms of anthurium yield in this study. Further based on the source-sink ratio, it is also possible to suggest there is a limit on the capacity of the sink (inflorescence) to allocate photoassimilates produced by the source.

Regardless of treatment with the growth regulator or water, the plants produced $6.48 \pm 0.38$ inflorescences year ${ }^{-1}$, a figure near that observed in other studies (NOMURA et al., 2009; 2011) with plants of the same cultivar. Unlike the increase in leaf area, the number of inflorescences produced by the plants declined during some months (Figure 1), but it would be necessary to analyze production over several years to establish whether climate or physiological conditions caused this fall in yield. In any event, this tendency has been observed in other studies in colder months of the year (DUFOUR \& GUÉRIN, 2003).

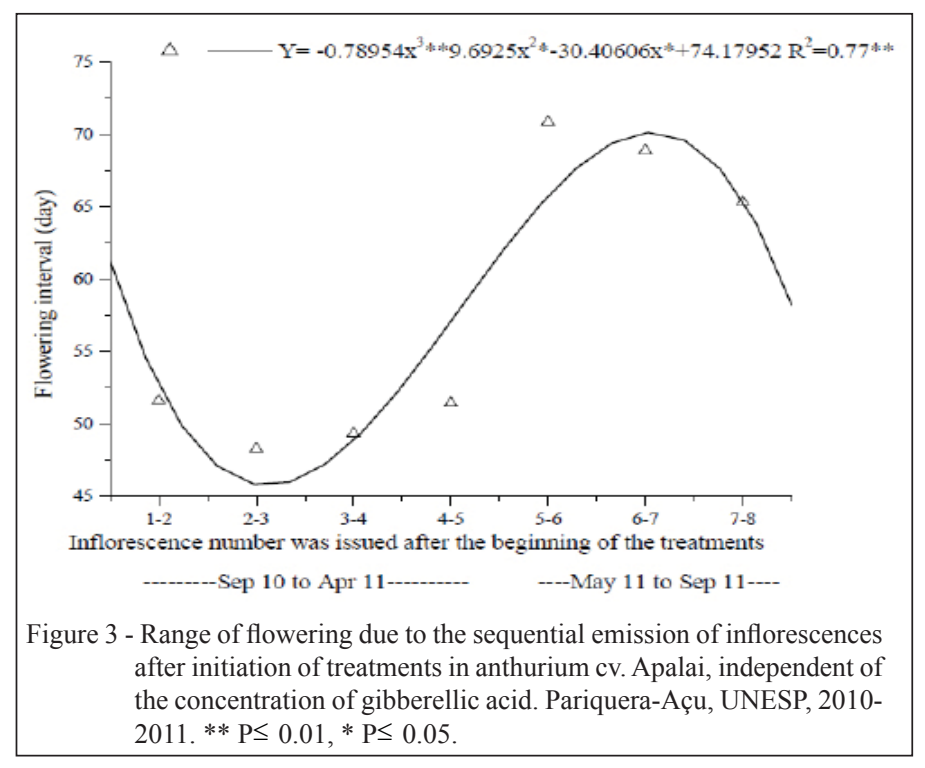

Ciência Rural, v.44, n.8, ago, 2014. 
The flowering interval also was not influenced by the different $\mathrm{GA}_{3}$ concentrations, but it did vary in function of the leaf sequence of the plant (Figure 3). The first, second, third and fourth leaves, produced from September 2010 to April 2011, presented a shorter average interval $(50.18 \pm 1.63$ days $)(\mathrm{P} \leq 0.05)$ in comparison with the fifth, sixth and seventh leaves,

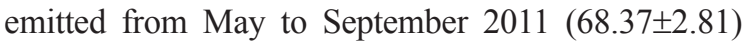
(Figure 3). The difference of 18 days for inflorescence emission in the two periods probably occurred due to the different prevailing climate conditions (Figure 1). It takes 60 to 80 days for good development of floral stems (DAÏ \& PAULL, 1990), indicating that from a quantitative standpoint, the yield observed in the experimental period was adequate for commercialscale production. In Londrina, located in the north of the state of Paraná in southern Brazil, ASSIS et al. (2011) noted a reduction in the yield of inflorescences of the 'Apalai' in a shorter period of the year (May to July), attributed to the decreased temperature along with the lower light intensity and shorter days.

In literature, the beneficial effects of gibberellin on anthurium were associated the floral initiation, increased number of inflorescences and its dimensions, however, this study the application of $\mathrm{GA}_{3}$ did not affect the dimensions of the inflorescences harvested, with the only variable having this effect being the time after the start of the treatments (Figure 4). The floral stem length, spathe width and length and spadix length, irrespective of the treatment, increased linearly with the leaf emission sequence (Figure 4). An increase in the size of inflorescences with increasing plant age was also observed in other studies (VAN HERK et al., 1998; DUFOUR \& GUÉRIN 2003; ASSIS et al., 2011) indicating that this behavior is characteristic of the specie. The spathe, length and width and spadix length presented mean values, respectively, of 11.78, 14.40 and $8.45 \mathrm{~cm}$, in all cases greater than in other studies carried out with the same genotype (NOMURA et al., 2009; 2011). After the emission of the seventh leaf, the average inflorescence length reached $60 \mathrm{~cm}$, the lowest value considered for flower classification (LOGES et al., 2005).

The appearance of the inflorescences also was not affected by the $\mathrm{GA}_{3}$. Of the 238 inflorescences harvested in the study period, $49(20.49 \%)$ had defects that prevented their sale. However, only $4.08 \%$ of the inflorescences harvested between September 2010 and April 2011 had defects, against 95.91\% of those harvested between May and September 2011, with spathe deformity being the most common flaw. This

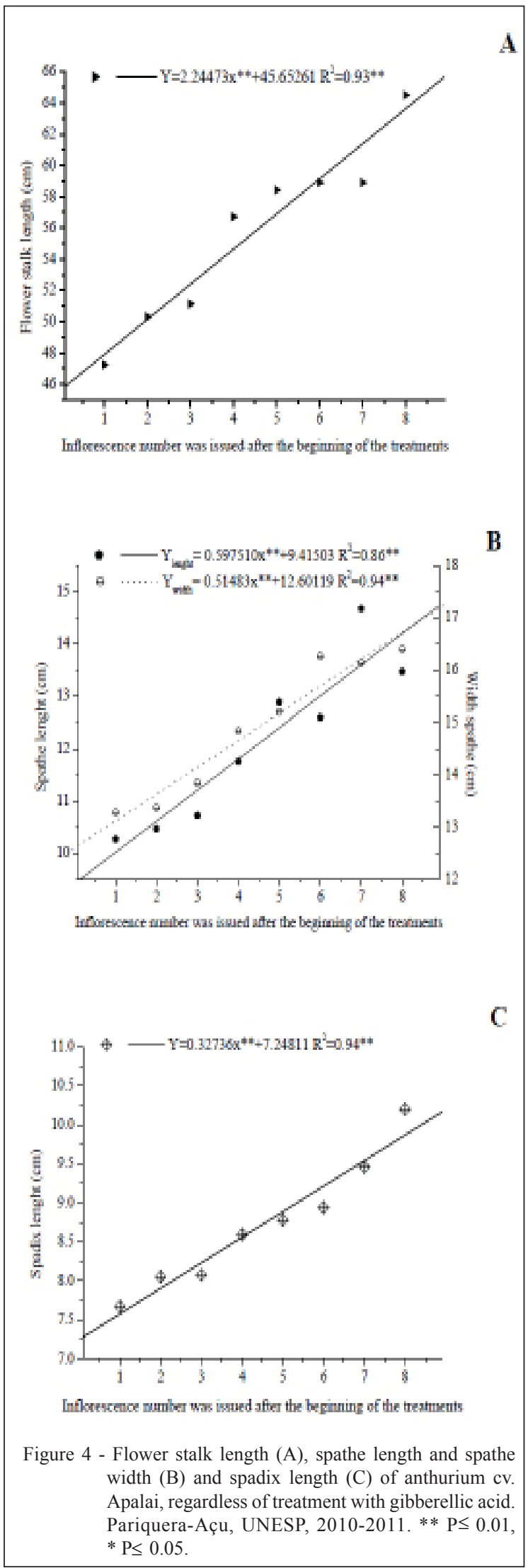

Ciência Rural, v.44, n.8, ago, 2014. 
is probably related to the different prevailing climate conditions in the period and the growth of the floral structure. Anthurium flowers produced in China when the average daily temperature was lower than $15^{\circ} \mathrm{C}$ also presented this symptom of damage by cold (GAO et al., 2002).

The absence of a response in the number of inflorescences to the treatment with $\mathrm{GA}_{3}$ observed, in contrast to other studies, can be attributed to the frequency of application of the growth regulator and differences in plant management. In other producing countries, the cut flower is generally maintained with four leaves, and the young leaves are periodically removed from the plants to prevent competition with the inflorescence. Nevertheless, the response of anthurium to treatment with $\mathrm{GA}_{3}$ only in the vegetative part of the plant argues against recommending the application of this growth regulator by commercial flower growers.

\section{ACKNOWLEDGMENTS}

To Fundação de Amparo à Pesquisa do Estado de São Paulo (FAPESP) and Fundação para o Desenvolvimento da Unesp (FUNDUNESP) for financial support.

\section{REFERENCES}

AMBER, L. et al. Gibberellin Signaling: a theme and variations on DELLA repression. Plant Physiology, v.160, n.1, p.83-92, 2012. Available from: <http://www.plantphysiol.org/content/160/1/83. full.pdf+html>. Accessed: Ago. 31, 2013. doi: http://dx.doi. org/10.1104/pp.112.200956.

ASSIS, A.M. de et al. Adaptation of anthurium cultivars as cut flowers in a subtropical area. Pesquisa Agropecuária Brasileira, v.46, v.2, p.161-166, 2011. Available from: <http://www.scielo.br/ pdf/pab/v46n2/v46n02a07.pdf>. Accessed: Jul. 24, 2012.

BOSCHI, C. et al. La aplicación de ácido giberélico en Anthurium scherzerianum. Respuestas sobre el follaje y la inflorescencia. Revista de la Facultad de Agronomia, v.18, p.89-92, 1998.

GAO, H. et al. Effect of temperature on Anthurium andraeanum growth and development. Subtropical Plant Science, v.31, Issue z1, p.65-68, 2002. Available from: <http://caod.oriprobe. com/articles/5458202/Effect of temperature on Anthurium andraeanum_growth_and_development.htm $>$. Accessed: Jul. 0 $\overline{4}$, 2012 .

CHANDARAPA, J.V. et al. Influence of growth regulators and their combinations on growth and flower production in anthurium cv. Royal Red. Research on Crops, v.7, n.1, p.279-281, 2006.

DAII, J; PAULL, R.E. The role of leaf development in Anthurium andraeanum inflorescence growth. Journal American Society Horticulture Science, v.115, n.6, p.901-905, 1990.
DUFOUR, L; GUÉRIN, V. Growth, developmental features and flower production of Anthurium andreanum Lind. in tropical conditions. Scientia Horticulturae, v.98, 1, p.25-35, 2003. Available from: <http://192.192.148.121/hhf/data/attach/1 adnKi3.pdf>. Accessed: Jul. 04, 2012. doi:10.1016/S03044238(02)00196-6.

DUFOUR, L; GUÉRIN, V. Nutrient solution effects on the development and yield of Anthurium andreanum Lind. in tropical soilless conditions. Scientia Horticulturae, v.105, n.2, 269-282, 2005. Available from: <http://nhjy.hzau.edu.cn/kech/ ssyy/qysd/wtzp/13.pdf>. Accessed: Fev. 04, 2012. doi:10.1016/j. scienta.2005.01.022.

HATIBARUA, P. et al. Production of quality Anthurium andreanum Lind as affected by some growing regulating chemicals. In: SINGH, V.B. et al. Horticulture for sustainable income and environmental. New Delhi: Concept Publishing, 2006. p.347-350.

HENNY, R.J.; HAMILTON, R.L. Flowering of anthurium following treatment with gibberellic acid. HortScience, v.27, p.1328, 1992.

HIGAKI, T. et al. A study of some morphological and anatomical aspects of Anthurium andraeanum Lind. Honolulu: University of Hawaii, 1984. 12p. (HITHAR Research Series, 30).

LOGES, V. Colheita, pós-colheita e embalagem de flores tropicais em Pernambuco. Horticultura Brasileira, v.23, p.699-702, 2005. Available from: <http://www.scielo S0103-84782008000100040>. Accessed: Fev. 04, 2012.

MIYAMOTO, T. et al. Rapid and orthogonal logic gating with a gibberellin-induced dimerization system. Nature Chemical Biologic, v.8, n.5, p.465-470, 2012. Available from: <http://www. jhu.edu/inouelab/pdfs/21.pdf>. Accessed: Ago. 30, 2013. doi: 10.1038/NChemBio.922.

NOMURA, E.S. et al. Crescimento e produção de anthurium submetido a diferentes intensidades de desfolha. Ciência Rural, v.41, n.4, p.602-607, 2011. Available from: <http:// www.scielo.br/scielo.php?script $=$ sci_arttext\&pid $=$ S0103$84782011000400009 \& \operatorname{lng}=\mathrm{pt} \& n \mathrm{~nm}=\mathrm{iso} \& \operatorname{tlng}=\mathrm{en}>$. Accessed: Mar. 04. 2013. doi: 10.1590/S0103-84782011005000043.

MARTIN, K.P. et al. Direct shoot regeneration from lamina explants of two commercial cut flower cultivars of Anthurium andraeanum Hort. In Vitro Cellular e Developmental Biology - Plant, v.39, n.5, p.500-504, 2003. Available from: <http://www. springerlink.com/content/h542634g36432j10>. Accessed: Mar. 04, 2012. doi: 10.1079/IVP2003460.

MODENESE-GORLA DA SILVA, S.H. et al. Estimativa da área foliar do antúrio com o uso de funções de regressão. Ciência Rural, v.38, n.1, p.243-246, 2008. Available from: $<\mathrm{http}: / /$ www.scielo.br/pdf/cr/v38n1/a40v38n1.pdf $>$. Accessed: Mar. 04, 2012.

NOMURA, E.S. et al. Crescimento e produção de antúrio cultivado sob diferentes malhas de sombreamento. Ciência Rural, v.39, n.5, p.1394-1400, 2009. Available from: <http://www.scielo.br/pdf/cr/ v39n5/a14v39n5.pdf>. Accessed: Fev. 05, 2012. 
NOMURA, E.S. et al. Crescimento e produção de anthurium submetido a diferentes intensidades de desfolha. Ciência Rural, v.41, n.4, p.602-607, 2011. Available from: <http:// www.scielo.br/scielo.php?script $=$ sci arttext\&pid $=\mathrm{S} 0103$ $84782011000400009 \& \operatorname{lng}=$ pt\&nrm=iso\&tlng=en $>$. Accessed: jul. 04, 2012. doi: 10.1590/S0103-84782011005000043.

SOIL SURVEY STAFF. Keys to soil taxonomy. 11.ed. Washington, D.C.: USDA-Natural Resources Conservation Service, 2010. 346p.

STANCATO, G.C.; SILVEIRA, A.P.D. Associação de fungos micorrízicos arbusculares e cultivares micropropagadas de anthurium. Bragantia, v.65, n.3, p.511-516, 2006. Available from: $<$ http://www.scielo.br/scielo.php?script=sci_arttext\&pid=S00
06-87052006000300018>. Accessed: Jul. 04 2012. doi: 10.1590/ S0006-87052006000300018.

TOMBOLATO, A.F.C. et al. Recursos genéticos e melhoramento do anthurium (Anthurium andraeanum Linden) no IAC-APTA Revista Brasileira de Horticultura Ornamental, v.10, n, 1/2, p.1$5,2004$.

VAN HERK, M. et al. Cultivation guide Anthurium: global know-how for growers around the globe. Bleiswijk, Holland: Anthura B.V. (Ed.), 1998. 140p.

ZHENG, F.; CHAO, W.Z. Effect of different hormones on flowering of Anthurium scherzerianum. Journal of Agricultural University of Hebei, v.27, p.51-53, 2004 